\title{
THE GASTRULATION AND EMBRYO FORMATION IN AMIA CALVA.
}

\author{
$\mathrm{BY}$ \\ ALBERT C. EYCLESHYMER AND JAMES MEREDITH WILSON.
}

From the Anatomical Laboratory of St. Louis University.

With 4 Double Plates.

In an earlier paper entitled "The Egg of Amia and Its Cleavage," Whitman and Eycleshymer, 96, described the development from the time of fertilization up to and including the late blastula. The present paper is a continuation of the earlier study, and deals with the changes taking place between the late blastula and the time when the tail of the embryo. becomes free from the yolk; that is, from the time of the late blastula until the time when most of the organs are laid down.

The material was killed in Flemming's fluid, Perenyi's fluid, chromosmic acid, picro-acetic acid, picro-sulphuric acid and corrosive sublimate-acetic acid. For surface views, chrom-osmic acid gives most perfect pictures; the osmic acid blackens the lines of cleavage so that they stand out in bold relief. Another excellent method for surface study is faint staining with Delafield's hæmatoxylin which may be employed after any of the above-named fixing solutions. The best seriak sections have been obtained after fixation in picro-acetic acid. Owing to the crumbling of the yolk we have been compelled to use celloidin as an imbedding mass. Serial sections were made after the method described elsewhere by the senior author, 9r. Staining in toto is best accomplished by using Czoker's alum-cochineal for from twenty-four to forty-eight hours. Staining in section with Mayer's hæmalum and alcoholic carmine has proved very satisfactory.

So far as the writers are aware, but two papers have been published dealing with the phases of development under consideration. Both of these appeared in 1896. The first was published by Sobotta and contains a fairly accurate, but incomplete, description of the gastrulation stages. The illustrations, however, are few and highly diagrammatic. The second was written by Bashford Dean and is more extended, but less accurate. Dean's descriptions unfortunately were based upon the erroneAmmican Journal of Anatomy.-Vol. V. 
ous assumption that the egg of Amia is meroblastic. In view of these facts, the present writers have thought that a renewed study of these phases of development might be profitable.

The ages given in the following description of stages have been determined from material taken from a single nest. The eggs were taken from the nest and placed in dishes which were submerged in the lake, a constant temperature of about $16^{\circ} \mathrm{C}$. being thus maintained. It is well known that no two spawnings progress at precisely the same rate. It is thus obvious that the ages designated are only in a general way indicative of the degree of development. We have, therefore, given measurements of the extent of the blastodisc and embryo in addition to the age.

The description of the latest stage studied by Whitman and Eycleshymer reads as follows: "The calotte, which has now begun to extend over the yolk, consists of thickly crowded spherical cells which marginally pass abruptly into the large yolk segments, while in the central portion they gradually increase in size and lie loosely scattered. The outer layer of the calotte is distinctly differentiated in that the cells are elongated and more densely granular. The entire yolk is irregularly cleft, the cells forming the lower portion are roughly polygonal and grade off into the larger yolk spheres which lie at the center." This stage of development indicates the beginning of our study.

\section{DETAILED DESCRIPTION OF STAGES.}

Egg Nine Hours After Fertilization. Blastodisc Covers About $100^{\circ}$ of the Circumference of the Egg.-A profile view of an egg of this age is shown in Fig. 1. An examination of the surface of the blastodisc shows an area at the upper pole of the egg in which cell division is most rapid. In addition to this, there are frequently found other areas in which cell division is accelerated. Often one side of the blastodisc is distinctly in advance of the other. Again, the most careful search results in a failure to detect such areas. We, therefore, are unable to say what relation, if any, these areas bear to the future embryo.

In all eggs of this stage the surface of the yolk is cleft by thirty to forty furrows which pass in meridional planes. Many of these grooves have not as yet reached the vegetative pole. Some never reach the pole, but pass obliquely into the longer ones. Through this process a number of long triangular segments are cut off at the upper margin of the yolk, as shown in the figure. At the lower pole, where fifteen to twenty grooves converge, the yolk is irregularly cleft. In general it may be said that the cleavage of the yolk as compared with the cleavage of the blastodisc is exceedingly slow. 
A study of meridional sections of many eggs in this stage shows that the blastodisc takes on different forms. In most eggs it is distinctly crescentic, but in some it is lenticular. When it takes on the crescentic form, as shown in Fig. 21, there is often a very distinct segmentation cavity (s. c.) present. The roof of the cavity is here made up of five or six layers of cells. The cells of the blastodisc contain finer granules than those contained in the large yolk segments. At the margin of the blastodisc, the cells pass over into those of the yolk by such imperceptible gradations that no sharp line of demarcation can be seen. The outermost layer of the blastodisc may be designated as the superficial layer of the ectoblast $(s . e c$.$) and as stated by Whitman and Eycleshymer it early ap-$ pears quite unlike the deeper ectoblastic layers (d.ec.), in that it possesses granules which stain more intensely than those in the other layers.

The upper ends of the yolk masses $(y . m$.$) are, in the egg shown,$ smooth and only at the margin are the cells being cut off. Other eggs, however, show that the large yolk masses at the center of the egg are actively contributing to the blastodisc. In the section shown (Fig. 21) the yolk nuclei lie near the upper margin of the large masses and this upper portion is probably to be considered as homologous with the periblast of bony fishes. Not more than one-third of the cleavage grooves observed on the surface of the yolk have reached the center of the egg, leaving the yolk masses incompletely cleft and thus forming a great syncytium.

Egg Twelve Hours After Fertilization. Blastodisc Covers About $110^{\circ}$. - The surface view (Fig. 2) shows that the rapid multiplication of the cells in the margin of the blastodisc has now given rise to greater uniformity in the size of all the cells of the blastodisc. Beyond this feature, surface views show no points worthy of special mention. Meridional sections (Fig. 22) show that the cells forming the superficial ectoblast (s.ec.) are smaller and more elongated than in the preceding stage. The lower layers of cells of the blastodisc are scattered through the upper portion of the segmentation cavity. The entoblastic cells, which have been cut off from the large yolk masses, are distinguished by their coarser granules and are also scattered through the segmentation cavity, many of them being found in its upper portion. Through these changes the segmentation cavity is more or less obscured.

Egg T'wenty Hours After Fertilization. Blastodisc Covering About $120^{\circ}$.- An egg of this stage (Fig. 3) shows a well-defined blastodisc with a sharply delimited margin in which, under the magnification given, cell boundaries are no longer distinguishable. No features have been observed which enable us to recognize the embryonic anlage. The yolk shows little advance in cleavage beyond that described in the preceding 
stage. In this particular egg the grooves, instead of following meridional lines as usual, diverge more widely than those in the eggs shown in Figs. 1 and 2.

Sections show, although none are figured, that the blastodisc in this stage is made up of eight to ten layers of cells which gradually pass over into the yolk derivatives. The outermost layer of the blastodisc has undergone still further modification in that its cells are more elongated, closely apposed and more deeply stained. The large yolk masses are actively budding off cells not only around the margin of the blastodisc but also in the central portion of the yolk. The yolk nuclei, which in the earlier cleavage stages, were confined to the upper portion of the yolk masses are now frequently found more deeply situated.

Egg Forty Hours After Fertilization. Blastodisc Covers $130^{\circ}-\mathrm{Al}$ though the surface of the egg, as shown in Fig 4, presents no features worthy of special comment, changes are going on in its interior which merit consideration. If a meridional section of an egg in approximately the same stage (Fig. 23) be examined it will be seen that the blastodisc proper is made up of from ten to twelve layers of cells so closely apposed that they make a compact stratum. In addition to these cells, there is a large number of loosely scattered cells which lie in the space which we have hitherto designated as the segmentation cavity. These loosely scattered cells gradually pass over on the one hand into the cells of the blastodisc proper and on the other into the large yolk masses. The cells. of the ten or twelve layers forming the upper portion are smaller, more uniform, more closely compacted and contain very fine granules as shown in the figure; while the loosely scattered yolk cells and those being budded off from the large yolk masses are larger, more irregular in outline and contain coarser yolk granules. These two portions cannot be considered as sharply marking off ectoblast and entoblast, since one finds in the portion which is largely ectoblastic, large cells which are filled with coarse granules; and if granules be the criterion for the separation of layers these cells must be regarded as recent derivatives from the large yolk cells which have wandered up from the lower portion of the blastodisc. If this interpretation be correct, it is a fact of some importance, since the part hitherto considered as exclusively ectoblast contains a considerable number of cells derived from the large yolk masses.

It has already been pointed out that the outermost layer of the ectoblast ( $s . e c$.) can be readily distinguished from the underlying layers. A glance at Fig. 23 shows that in the locality where this layer passes over into the large yolk cells there is a marked proliferation of its elements. A study of the remaining sections shows that as yet there is no invagination. 
This thickening of the superficial layer marks the anlage of the forthcoming dorsal lip $(d . l$.) of the blastopore. The margin of the blastodisc in the embryonic region has a more rounded contour than at the opposite margin. It is also thicker and possesses a greater number of cells with fine granules; the periblast, too, is more actively engaged in budding off. derivatives in this region than at the opposite margin. These several factors enable us at this time to orient the forthcoming embryo.

The so-called periblastic nuclei are no longer confined to the upper margin of the large yolk masses, but are often widely scattered. These yolk masses sometimes contain several nuclei and the same is true of the scattered entoblastic cells. In other words, nuclear division here goes on far in advance of cytoplasmic division.

Egg Fifty Hours After Fertilization. Blastodisc Covers About $180^{\circ}$. - If the surface of the egg be carefully examined in a stage intermediate between Figs. 4 and 5, it will be found that just above the equator on the side of the blastodisc which is least transparent there is a slight indentation which indicates the beginning of the blastopore. As development progresses this indentation becomes a groove which extends in a latitudinal plane until it reaches the condition shown in Fig. 5, where it extends around some $20^{\circ}$ of the egg's equatorial circumference.

The meridional section represented in Fig. 24 is from an egg intermediate between those represented in Figs. 4 and 5. At this time, the blastodisc has taken a more definite form owing to the greater compactness of its layers. In extent it covers very nearly one-half of the egg's surface. It is noteworthy that at the time the blastopore appears the blastodisc reaches its maximal thickness.

In the particular egg described, the entoblastic cells are less densely aggregated than usual, with very large intercellular spaces, while the large yolk masses extend well up towards the lower layers of the blastodisc. In this respect we find considerable variation. In some eggs they are even less densely aggregated than shown in Fig. 24 so that a well-marked segmentation cavity $(s . c$. ) is shown between the large yolk masses and the blastodise.

In the stage under consideration we have the first actual appearance of the invagination to form the archenteron. As to the factors which initiate this process, we are as much in the dark as ever. Without attempting to discuss the various theories, we may simply say that thus far there is an infolding of the external layer and that this infolding is not in the locality where the transition between large and small cells is most abrupt, but in a locality where the superficial cells are largest and of fairly uniform character. One would at first glance think the in10 
vagination were wholly in the part of the surface layer which belongs to the epiblast. A comparison with other forms, however, such as the various Amphibia, leads one to hesitate in such an interpretation. The crucial factor is the determination of the limits of the ectoblast. If the ectoblast be considered as extending to the point where the smaller cells pass over into the large yolk masses, then the invagination is in the ectoblast. If it does not extend to this point, there are no features which will enable us to determine how far it does extend.

A more highly magnified view of the blastoporic region is shown in Fig. 25. The section is taken from an egg of the same age as that shown in Fig. 24. In many eggs of this stage, there is a stratum or tongue of cells which is somewhat peculiar. This stratum is directly continuous with the deep ectoblast at the dorsal lip of the blastopore. Anteriorly its cells are separated from the deep ectoblast by the segmentation cavity above, while below they pass over into the entoblastic cells. In this stratum which is from four to five layers thick, two kinds of cells are present. The more numerous are cells which conform in structural peculiarities to those of the deep ectoblast. The less numerous are cells which possess the structural features of the entoblast. This layer of cells Sobotta, 96, has described as mesoblast. Since this layer not only contains mesoblast but also entoblast, we have decided to designate the layer as mes-entoblast (m.en).

In Fig. 26 there is represented a meridional section of an egg somewhat older than that just described, but younger than that shown in surface view in Fig. 5. The archenteron or gastral cavity is more extended and its dorsal wall is formed of cells which are so much like those of the superficial ectoblast that one is inclined to regard invagination as still playing the more important rôle. The rounded cells at the end of the gastral cavity are further confirmation. In short it may be said that thus far there are no reasons for considering delamination as a factor of any importance in the formation of the gastral cavity.

No particular changes are noticed in the character of the cells in the region where the head of the embryo is about to appear. The yolk derivatives are widely scattered in the segmentation cavity and many cells which, from the character of their granules, would be called yolk derivatives are still to be found scattered among the ectoblast cells. The large yolk masses are still actively budding off cells and this process has gone on so rapidly in this particular egg that these masses have become greatly reduced in size.

Egg Fifty-three Hours After Fertilization. Blastodisc Covers About $200^{\circ}$. The anlage of the embryo can now be faintly recognized in sur- 
face view (Fig. 5). It first appears as a light area with ill-defined outlines extending over some $80^{\circ}$ towards the upper pole, where it shades off imperceptibly into the remainder of the blastodisc. That portion which is invaginated to form the dorsal lip of the blastopore stands out more prominently from the yolk than elsewhere. The line of invagination now extends some $60^{\circ}$ along the margin of the blastodisc and appears as a crescentic fissure.

A meridional section of an egg in a stage closely corresponding to that described above is represented in Fig. 2\%. Although this egg is but slightly older than the one shown in Fig. 26, some interesting changes have occurred. In the preceding stage the deeper ectoblast was seven or eight layers of cells thick; now it is only two or three. The embryonic margin of the blastodisc has likewise undergone a reduction, while the opposite side of the blastodisc is reduced to one-half the number of layers present in the preceding stage. In addition to these changes, the stratum of cells which we have designated as mes-entoblast extends well up toward the upper pole of the egg and it is probably through the extension of this layer that the surface views show faintly the anlage of the embryo.

In most eggs in this and subsequent stages, there are relatively few entoblastic cells as compared with the earlier stages. The space which in most of the earlier stages was filled with small cells is now filled with large yolk masses with a few smaller cells scattered among them. It is possible that many of the entoblastic cells have found their way into the rapidly extending blastodisc.

Fig. 28 represents a section of the blastoporic end of the embryo under much higher magnification. The section is taken from another egg in about the same stage of development as that shown in Fig. 2\%. It will be here noted that the gastral cavity is lined above by a single layer of cells which strikingly resemble those of the superficial ectoblast in size, granular contents and staining capacity. The same can be said of the cells forming the ventral wall. The cells of this wall rest in this section upon the large yolk masses whose margins are regular and clearly delimited. A peculiar feature which was noticed in the preceding stage, but is here more clearly shown, is the striking differentiation of the innermost layer of the deep ectoblast. These cells stain more deeply than the remaining cells of this stratum.

Fig. 29 represents a meridional section of an egg in a stage somewhat later than that last described, but earlier than the stage shown in Fig. 6 . The blastodisc has undergone continual thinning at the upper pole until at present it is but two or three layers of cells thick. At the blastoporic margin the blastodisc is thickened, while on the opposite side of the egg 
a slighter thickening of the margin gives rise to a condition which reminds one of the germ-ring of the teleost.

An equatorial section, taken just above the equator of an egg in the same stage, is shown in Fig. 30. The ectoblast in the embryonic region is much thicker than elsewhere, and from this region of greatest thickness it shades off gradually on either side, showing that at this time there are no well-defined lateral boundaries of the embryonic anlage. Just beneath the median portion of the embryonic anlage there is a compact arrangement of the mes-entoblastic cells which represents the beginning of the notochord $(c h)$.

Egg Fifty-five Hours After Fertilization. Blastodisc Covers About 240 $0^{\circ}$. Embryo Extends Over $110^{\circ}-120^{\circ}$.- The embryo now presents a profile (Fig. 6) which may be spoken of as somewhat triangular. Its anterior portion fades out in the region of the upper pole of the egg. Its posterior portion, however, is more sharply defined owing to its being deeply infolded at the blastoporic margin. In many embryos of this stage, there is present a median thickening in the blastoporic margin which may doubtless be considered as the homologue of the caudal knob of the teleosts. The lower portion of an egg in about the same stage is shown in Fig. 7. It will be noticed that the margin of the blastodisc is not only deeply infolded along the base of the embryo, but also slightly infolded on the opposite side of the egg. A comparison of Figs. 6 and 7 with Fig. 5 shows that the surface cleavage of the yolk is very slow.

A meridional section of an egg in this stage is shown in Fig. 31. The embryonic anlage here shows as a thickening of the ectoblast. The area of maximal thickness $(h)$ near the upper pole of the egg represents the anlage of the head. In this region the superficial ectoblast shows no changes, the thickening being due to the proliferation of the deeper ectoblast which is now twelve to fourteen layers thick as compared with six to eight in the preceding stage. The deeper layers decrease in number throughout the anterior trunk region and again increase at the blastoporic margin. In front of the anlage of the head $(h)$, the deep ectoblast becomes thinner until, in the region of the equator, it is but a single layer thick; beyond this region it again thickens and at the blastoporic margin is three or four layers deep.

The segmentation cavity, which in the preceding stage extended over the greater portion of the upper hemisphere, is no longer present above the level of the equator. The layer of ectoblastic cells forming its roof is still sharply diffrentiated from the other layers of the ectoblast.

The gastral cavity $(g . c$.) has extended cephalad to the level of the posterior third of the embryo. Behind the dorsal lip of the blastopore, it 
extends around on either side of and behind the large yolk plug where it is continuous with that part of the cavity which is everywhere lined externally by a sharply differentiated layer of hypoblast. At the blastoporic margin, this layer of hypoblastic cells changes in character from the small elongated cells with deeply staining granules to larger cuboidal cells and these in turn shade off into the smaller elongated cells of the superficial ectoblast. The floor of the anterior portion of the gastral cavity is made up of entoblastic cells which are heavily laden with large yolk granules. Toward the exterior these cells increase in size as they extend over the sides of the yolk plug until they finally become continuous with the great yolk masses $(y . m$.)

The layers of mes-entoblast (m. en.) not only extend much farther forward in the embryonic region but also become well differentiated in the extra-embryonic portion of the blastodisc. By tracing these layers in serial sections it is readily found that the anlage of the mesoblast is peristomal.

Embryo Sixty Hours After Fertilization. Blastodisc Covers About 245 . Embryo Extends Over $130^{\circ}$.- The outline of the embryo as yet is indistinct in the anterior region, but fairly well defined posteriorly (Fig. 8). The entire margin of the blastodisc is deeply infolded around the projecting yolk plug. In the posterior portion of the embryo, there is a shallow groove present. A comparison with other embryos in this same stage shows that this groove is variable, being sometimes more and sometimes less pronounced. Sometimes it terminates posteriorly in a deep indentation in the margin of the blastopore much like the condition observed in Batrachus or Ameiurus; at other times there is a well-defined caudal knob.

The sagittal section represented by Fig. 32 is from an egg in the same stage. The deep ectoblast in the head region is notably thickened, being now twelve to sixteen layers in dorso-ventral thickness. In the trunk region these layers are further reduced while at the blastopore they remain practically unchangd. Anterior to the region of maximal thickness the deep ectoblast gradually thins until, as in the preceding stage, it is but one or two layers thick in the equatorial region; finally at the ventral lip there are four or five layers.

The mes-entoblast has extended farther toward the upper pole, but to just what extent it is impossible to say since the cells are here indistinguishable, on the one hand, from those of the deep ectoblast, and on the other, from those of the yolk. At the blastoporic margin where the cells of the mes-entoblast and the deep ectoblast unite, they form a sharp angle. In this angle there now appears a peculiar group of cells 
which has been derived from the mes-entoderm. We were at first inclined to regard these cells as exclusively mesodermal but since they later lose their distinctive character the question cannot be definitely settled.

A sagittal section of an embryo slightly later than the preceding is shown in Fig. 33. The principal changes are the further extension of the blastodisc and the corresponding reduction in the diameter of the yolk plug. The peculiar differentiation of the inner layer of the deep ectoblast is here prominent. The segmentation cavity is vanishing, the gastral cavity enlarging. The yolk is being rapidly segmented, especially at its periphery.

Embryo Sixty-five Hours After Fertilization. Blastodisc Covers About $355^{\circ}$. Embryo Extends Over About $140^{\circ}$.- The surface view of an egg in this stage is represented by Fig. 9. The embryo is now much better defined. The anterior portion is somewhat broader than the trunk, which in turn becomes narrowed towards the blastoporic end. The blastopore is almost closed. In its closure one rarely finds the condition so frequently found in the amphibia where the lateral lips approximate so much faster than the dorsal and ventral that a slit-like blastopore arises.

Embryo Seventy Hours After Fertilization. Embryo Extends Over About $154^{\circ}$. The next surface view (Fig. 10) represents an embryo about five hours older than that shown in Fig. 9. The features noted in addition to those described in the preceding stage are the further elongation of the embryo; the presence of a well-marked neural trench; the further closure of the blastopore. At this time there are no external evidences of optic vesicles, protovertebræ, or pronephric ducts.

A sagittal section of the posterior portion of an embryo in this stage is shown in Fig. 34. At this time the blastopore is nearly closed. The external epiblast, as in the earlier stages, is a single layer of cells which still retain their peculiar coarse granules and deep staining capacity. These cells are in direct continuity with the single layer of cuboidal cells lining the blastopore. These cuboidal cells in turn pass over into the elongated layer of hypoblastic cells which form the dorsal wall of the gastral cavity. The floor of the gastral cavity is made up for the most part of a single layer of entodermal cells. The appendicular portion of the gut $(a . g$.$) is lined by cells similar to those just described.$

A transverse section through the blastopore of an embryo in the same stage is shown in Fig. 35. The relation of the layers is here more clearly shown. It will be noted that the section shows especially well the great lateral sheets of mesoblast (mes.)

A median sagittal section of an embryo a few hours later is shown in Figs. 36 and 3\%. The anterior and middle portions are shown in Fig. 36, 
the posterior in Fig. 3\%. The general contour of the embryo shows some advance beyond the conditions shown in Figs. 34 and 35 . The head region shows a considerable increase in the number of ectoblastic cells, in the trunk region but two or three layers are present, while posteriorly they again show a marked increase in number. Just beneath the superficial ectoblast (s. ec.), there is now differentiated a second layer of elongated cells. These cells, however, possess granules which are similar in staining capacity to those of the deep ectoblast and have thus been considered as derivatives from the deeper layer.

In the mass of cells which makes up the anlage of the future brain, there is now observed a slight cavity (br. c.) which is the first appearance of a cavity in the central nervous system. In front of this mass of cells is a second thickening which has been designated as the pre-cerebral mass $(p . c b)$.

The notochord ( $c h$.$) is now well differentiated, being readily distin-$ guished from the surrounding tissues by the loosely scattered arrangement of its cells. It extends from the undifferentiated caudal mass of cells to the anlage of the future optic vesicles.

The gut has increased through both forward and lateral extension. In its anterior portion its dorsal and ventral walls are closely apposed, yet they can be readily traced as distinct layers to a point somewhat beyond the anterior end of the brain. In its middle and posterior portions it is widely open. Just anterior to the line of large yolk cells (bl.) which represent the closed blastopore, there is a dorsal diverticulum of the gut which has been regarded by others, as well as ourselves, as the homologue of Kupffer's vesicle.

Embryo Seventy-five Hours After Fertilization. Embryo Covers About $150^{\circ}$.- In Figs. 11 and 12 are represented the anterior and posterior portions of an embryo of this age. The anterior trunk region is narrower and two or three protovertebræ are now present. Lateral thickenings at the anterior end represent the beginnings of the optic vesicles. On either side of the anterior end, there is a darkened area which represents the lateral extension of the mesoblast.

An oblique section through the optic thickenings (op.t.) is shown in Fig. 38. The superficial ectoblast which is now double layered passes over these thickenings unmodified. No lumen is present in the central nervous system at this level, but in sections intermediate between those represented in Figs. 38 and 39 there is a slight fissure present. The mesoblast shows as two wide lateral bands (mes.) on either side of the neural rod or keel. The foregut is present, but the close approximation of its walls makes its lumen obscure. 
Another section of the same embryo through the posterior portion of the hind brain is represented in Fig. 39. On either side of the neural keel and in close proximity to its dorso-lateral margin, there are deeply staining groups of cells which are probably spinal ganglia; although it should be said that in some preparations they appear to be proliferations of the inner layer of the superficial ectoblast. The notochord (nc.) is well differentiated at this level. Beneath it the layers forming the walls of the gut are in contact so that the lumen is here obscured. On either side of the notochord, however, the layers separate and the laterally extending gut cavity $\left(g . c_{\text {. }}\right)$ is obvious.

Another transverse section at the level of Kupffer's vesicle is represented in Fig. 40. In the median line there is a groove in the superficial epiblast $(n . t$.) which we have interpreted as a neural trench. It extends backward to the point where the scattered coarsely granular cells indicate the line of closure of the blastopore ( $c f$. Fig. $3 \%$ ). The deeper epiblast has not yet taken on the form of a neural keel, but extends laterally to a considerable distance. The notochord is well differentiated and consists of cells whose character lends confirmation to the view that they are derived from the mesoderm rather than the gut hypoblast. At any rate we have not observed the coarsely granular cells of the hypoblast participating in its formation.

The section represented by Fig. 41 is taken through the posterior portion of an embryo of about the same age. In this embryo a deeper neural trench $(n . t$.$) is present than in the preceding. The posterior end of the$ notochord, as it passes over into the mass of undifferentiated cells is barely defined by the peculiar arrangement of its cells. Kupffer's vesicle is smaller than in the preceding embryo. In this structure there are wide variations in size as may be inferred by glancing at the different figures.

Embryo Eighty Hours After Fertilization. Embryo Covers About $160^{\circ}$.-The surface views (Figs. 13 and 14) show that the embryo is considerably advanced beyond the stage represented in Figs. 11 and 12. The body of the embryo is narrower; the optic vesicles are more prominent; seven to nine protovertebræ are differentiated; the pronephric ducts are forming. In the anterior portion of the embryo there are three fairly well defined regions which represent the primary divisions of the brain. Anterior to the optic vesicles the nervous system is continued into a conical process, the homologue of the structure which Salensky found in Acipenser and to which he gave the name "Stirnforsatz." This precerebral portion of the head is the anlage of several structures to which we shall hereafter refer in greater detail. The mid-brain is marked off by a constriction posteriorly and behind this constriction is a 
marked enlargement which forms the basis of the anterior portion of the medulla. In this region, as Keibel has pointed out, the anlage of the otic vesicles will later appear. The darkened zone around the anterior end of the embryo represents the extent of the mesoblast. Posteriorly the lateral boundaries of the mesoblast are poorly defined so that in surface views it is impossible to indicate them.

Embryo Ninety Hours After Fertilization. Embryo Covers About $180^{\circ}$ - Figs. 15 and 16 represent the anterior and posterior portions of an embryo in this stage. Many striking changes have occurred. The subdivisions of the brain are more clearly defined and are more prominent. The optic vesicles are better defined. The precerebral portion extends forward as a distinct process. The first visceral arch has formed and, just behind it, is the first visceral cleft. The protovertebræ have increased to sixteen or more pairs. The pronephric ducts have extended both anteriorly and posteriorly. There are at this time, however, no external indications of the olfactory, auditory or adhesive organs.

Fig. 42 represents a section passing close to the median sagittal plane of an embryo slightly younger than that shown in Fig. 1\%. The superficial ectoblast $(s$. ec.) consists of two layers of cells which are invaginated at a point lying between the anterior margin of the fore brain $(f . b$.$) and the median portion of the adhesive organs.$

The brain cavities are now well defined. There is, however, as yet no indication of the infundibular or epiphysial evaginations. The notochord extends nearly to the level of the middle portion of the brain, as shown in the figure. The gut cavity is well defined beneath the posterior portion of the brain; it is greatly reduced in size anteriorly. After reaching the level of the epiblastic invagination described above, it again expands into a wide cavity $(g . d$.$) . The walls of the gut show little change$ until the head region is passed when the dorsal wall is greatly thickened to form the beginnings of adhesive organs (a. o.).

A transverse section through the extreme anterior end of the brain is represented in Fig. 43. The superficial ectoblast shows no modification in this section. Just beneath this layer the deep epiblast extends over the surface, but in the median line it is lost in the mass of cells which are radially disposed and which represent the anterior end of the fore brain. Below the fore brain is a wide layer of mesoblast (mes.) which extends upward on each side. On either side of the median line the fore gut is greatly expanded. The layer of columnar cells covering these expanded portions, even at this early stage, is different from that forming the dorsal wall of the gut in other portions of the body. On either side the hypoblast extends peripherally, its cells take on the cuboidal form, 
and become continuous with the yolk. In the figure given the dorsal hypoblast has been too deeply shaded so that it is brought out in too strong contrast with the layer of yolk-bearing cells which form the floor of the fore gut. On either side of the gut the anterior extremities of the colomic cavities (c.) are present.

The next section described is represented in Fig. 44. The section passes through the optic vesicles (o.v.) which at this time are hollow and in wide communication with the fore brain. On either side there are slight depressions of the superficial epiblast which are probably artifacts due to killing reagents. The loosely scattered cells of the mesoblast (mes.) form two large masses which extend laterally from the region where the floor of the fore brain rests directly upon the gut hypoblast. Just beyond the lateral boundary of the fore gut the mass separates into two layers, an outer somatic which is closely united with the ectoblast and an inner splanchnic which lies close to the gut hypoblast. Between these two layers are the coelomic cavities $(c$.$) . The gut (f . g$.$) is here$ widely expanded and, on either side, are seen the hypoblastic cells as they pass over into the anlagen of the adhesive organs.

A section through the region where the mid brain passes over into the medulla is show in Fig. 45. The pharyngeal portion of the gut is here widely open and slight evaginations indicate the first appearance of the visceral clefts. Just external to these are mesoblastic masses (v. a.) which are the beginning of the visceral arches. The mesoblast extends down around the brain until it comes in immediate contact with the notochord. The walls of the cœlomic cavities (c.) are separated widely and are lined by a single layer of cells.

Passing still further back we have selected a section (Fig. 46) through the region of the auditory vesicles. The cavity of the medulla is here widely open. Its lateral walls are made up of elongated epithelial cells arranged in one or two layers. Its roof, however, is very thin, so that when viewed from the surface it is very transparent. On either side are the auditory vesicles (a. v.) which have formed from thickenings of the deeper ectoblast. Above these the two layers of the superficial ectoblast are continuous. The vesicles which were earlier solid now show very small lumina. Just external to the vesicle on the right side there is a diverticulum of the gut, the pharyngeal portion of the third cleft, while just outside this, a thickening in the mesoblast is the third arch. The cells of the hypoblast forming the dorsal wall of the gut are flattened, but in the region of the clefts they become cuboidal, which character they retain until they pass over into the yolk cells. The ventral wall of the gut is 
still formed by a loosely scattered layer of entodermal cells which lie above the large yolk masses.

The last section of this embryo, which we have represented in Fig. 47, is taken at the level of the last protovertebra. In this section we see that the neural keel of the earlier stages has taken on a cylindrical outline and has acquired a large well defined lumen in which there are no traces of cell degeneration. Below the neural tube and in contact with it, is the large notochord, and between the notochord and the gut hypoblast, is the sub-notochordal rod $(h . c h$.) which, from the character of its cells, seems to have arisen from the hypoblast of the gut.

On either side of the notochord, are the large masses of mesoblast which form the last protovertebræ. At this level, the mesoblast shows no line of division between its somatic and splanchnic portions. In that portion which must be considered as potentially somatic, there is a slight proliferation which gives rise to a more or less well defined rod ( $p . d$. which soon becomes the pronephric duct.

Embryo About One Hundred and Five Hours After Fertilization. Embryo Surrounds $220^{\circ}$.- The embryo (Fig. 17) shows a marked advance beyond the condition represented in Figs. 15 and 16 . The divisions of the brain are more distinct. The hind brain shows a decided thinning of its dorsal wall. In front of the anterior end of the fore brain there is a slight pocket followed by a projection or median knob. On either side of this knob, are the large adhesive organs which are now apparent in surface view. The large optic vesicles lie just behind, and now show the first beginnings of the lenses. On either side of the medulla the auditory vesicles are faintly shown. The pronephric ducts have extended both anteriorly and posteriorly. The anterior portion of an embryo about five hours older is shown in Fig. 18.

In this stage but few changes are noted beyond those described. The lateral walls of the medulla are more widely separated and the roof has become thinner. The visceral arches and clefts are more pronounced. There is no trace as yet of the olfactory organs. As a result of the uplifting of the embryo through growth, the adhesive organs have assumed an oblique position.

A sagittal section, passing slightly to one side of the median plane of an embryo in this stage, is represented in Fig. 48. The lumen of the brain is enlarged and its subdivisions more clearly marked. The dorsal wall of the fore brain now shows a slight evagination which is the beginning of the epiphysis. Just opposite in the floor is another evagination which is the beginning of the infundibulum. Anteriorly the cavity narrows down in conformity with its external contour. Just in front of 
the anterior end of the fore brain, the continued invagination of the superficial epiblast gives rise to a deep pocket in which a lumen is sometimes plainly apparent, while at other times its walls are so closely apposed that no lumen is discernible. The fore gut is here well shown with its forward extension into the precerebral region where it ends in a dilated cavity. The walls of this cavity, except the ventral, are made up of elongated hypoblastic cells. Just beneath this median evagination there is a large chamber surrounded by a double wall. The lining wall is made up of elongated cells which strongly resemble those lining the body cavity. Outside this layer is a second wall made up of large yolkladen entoblastic cells. This chamber represents the beginning of the heart. The discussion of its formation, however, may best be deferred until we have studied the series of transverse sections of the next stage.

Embryo One Hundred and Twenty-five Hours After Fertilization. Embryo Covers $260^{\circ}$.- The last stage of the embryo included in the present study is represented in Figs. 19 and 20, the anterior portion being shown in Fig. 19, while the posterior is represented by Fig. 20. The embryo has increased greatly in length and its body is more prominent above the surface of the yolk, while the tail is just becoming free from the yolk. The increase in the length of the head has caused further shifting in the position of the adhesive organs which, instead of having their surfaces directed above, have come to occupy such an oblique position that their surfaces are almost directed forward. The so-called "button" (Reighard) is likewise carried forward and is no longer visible when the embryo is viewed from the dorsal surface. Just behind the adhesive organs are the two nasal pits which are visible for the first time in surface views. In the eyes, the lenses are plainly shown in the surface views. The mid brain has extended backward, while the hind brain has pushed forward in such a manner that its anterior portion envelops the posterior portion of the mid brain. In this embryo, the roof of the hind brain has been removed and one can plainly see in its floor a number of neuromeres. These are variable in the different embryos of this age, ranging from six to eight. On either side of the hind brain, the auditory vesicle shows as a deep pit. Three visceral arches are now well defined, as are also the three visceral clefts which appear as darker portions between them. The cœlomic cavity shows as a darker circle around the margin of the embryo, although its boundaries are not as clearly defined as in some of the earlier stages. (Fig. 17). The proto. vertebræ have extended on either side until they now reach from the extreme posterior end nearly up to the auditory pits. The pronephric ducts have extended both anteriorly and posteriorly. At their anterior ends they curve outward, then inward, in the form of a shepherd's crook. 
A transverse section of an embryo in this stage is represented in Fig. 49. This section is taken through the region just anterior to the adhesive organs. On either side the cœlomic cavities show plainly as they approach the median line. The layers of the splanchnopleure are thus brought in such close contact above that the gut $(g$.$) is almost closed off.$ During the time these layers are approaching they become folded backward into the cœlom on either side. In the figure, the left side is considerably in advance of the right. Through this folding there is formed a second closed cavity $(h t$.) which is the beginning of the heart. There is present at this time a lining layer, but its origin is uncertain.

The section represented in Fig. 50 passes somewhat obliquely through another embryo in about the same stage of development. The anterior end of the fore brain $(f . b$. ) appears as a solid mass of elongated cells. In connection with its ventral wall, the optic stalk passes obliquely outward and terminates in the optic vesicle. On the other side the section passes through the anterior portion of the adhesive organ which here shows its connection with the anterior end of the fore gut $(g$.$) . The$ fore gut is almost closed off ventrally through the approximation of the colomic cavities. Between the end of the brain and the optic vesicles, there is a slight invagination $(n$.) of the deep ectoblast to form the beginning of the nasal pits.

The section represented in Fig. 51 is from the same series as the preceding and three sections farther back. The section through some oversight is not magnified quite so highly. The chief point of interest, as compared with the preceding is the rapid separation of the colomic cavities so that the gut is here widely open upon the yolk. It should also be noted that the carities of the optic stalk, the fore brain and the adhesive organs are becoming apparent.

A section of the same series is shown in Fig. 52 at the level of the auditory vesicles. The section shows the extension of the cavities of these vesicles (a. v.) In other respects the section shows nothing more than is shown in Fig. 46.

The section shown in Fig. 53 is taken in a horizontal plane and shows practically all the structures which have been described in the series of transverse sections. The divisions of the brain are very clearly shown. Just in front of the anterior end of the fore brain is the invagination of the superficial ectoblast which we have previously described. On either side are the nasal pits $(n$.) with well defined lumina. Just anterior to these are the adhesive organs (a. o.) made up of the coarsely granular hypoblastic cells. Behind these are the large optic vesicles $(o . v$.$) in$ 
which the lenses are present, but not shown. Behind these in turn are three gill clefts $(v . c$.$) and between them the mesoblastic bases of the$ corresponding arches. Close to the medulla are the auditory vesicles (a. v.). Around the periphery the lines of darker cells represent the hypoblastic walls of the gut $(g$.$) The section is cut so thick that the$ mesoblast shows above, making it almost appear as if the gut were filled with these cells.

\section{SUMMARY AND GENERAL REMARKS.}

\section{The Segmentation Cavity.}

Before considering the stages which properly belong to the present paper, we are obliged to say a few words concerning the segmentation cavity. Whitman and Eycleshymer, 96, pointed out that there are to be found in the egg, even in the earliest cleavage stages, certain irregular cavities which sooner or later become continuous with the cleavage grooves and in many cases unite to form a common cavity. These cavities appear in eggs collected in different years and in different seasons of the same year and fixed and imbedded in various ways. Since it is from these spaces that the segmentation cavity later takes its origin they have been subjected to renewed study. As segmentation progresses the cleavage grooves, in many cases at least, expand into broad spaces as they approach the center of the egg, in which locality they become continuous with the earlier spaces described above. Often these cavities unite and give rise to a more spacious one as figured by Whitman and Eycleshymer. That the cavities should be regarded as artifacts seems highly improbable. In the first place no cellular fragments are to be found in the spaces which would indicate imperfections in cutting. Again these cavities often shade off by imperceptible degrees into veritable intercellular spaces which no one would consider as artifacts. As the later stages of the blastula approach, the cavities no longer show as large irregular spaces, but become more or less obliterated by being filled with the rapidly proliferating cells of the blastodisc and yolk. In view of these facts, we cannot agree with Sobotta, 97, that these cavities are artifacts.

\section{Pertblast.}

The periblast in ganoids was first discussed by Dean, 95, 96, who pointed out the homology of the upper layer of yolk cells in Acipenser, Lepidosteus and Amia with the periblast of teleosts. Sumner, oo, later gives two figures showing the periblast in Amia. In one of these (Fig. 16) he represents a well defined, clear zone lying on the large yolk masses 
and covered by a cellular layer which is considered as periblast. The author states that the figure is slightly schematized, but to what part of the figure he refers is uncertain. If to the periblast we have no criticism to offer. If the author, however, intended to represent the periblast as it is actually found in Amia we must emphasize the fact that our material shows nothing of the sort. There is no layer of cells between the periblast and the gastral cavity. The floor of the gastral cavity is, to our minds, the homologue of the periblast in teleosts. We find in the ganoids a complete series of gradations from the teleostean to the amphibian conditions. In repidosteus, as described and figured by the senior author, 03, we find the closest approach to the teleostean periblast. Amia comes next with its homologous layer in the floor of the gastral cavity; this floor is made up in part of detached cells and in part by the projecting ends of the large yolk masses. From this condition we can readily pass to the homologue of the periblast in Acipenser which is the layer of cells forming the floor of the gastral cavity. We are thus prepared to support the statement of the Zieglers, 92, that the floor of the gastral cavity in the amphibia is the homologue of the periblast in fishes.

\section{The Mesoderm.}

The origin of the mesoderm in Amia has been previously studied by both Dean and Sobotta. Their descriptions, however, are quite unlike.

Dean, 96, in describing a stage in which the blastopore has nearly closed, says: "The mesoblast is found to arise peristomal; on the dorsal side it arises from the undifferentiated tissue (of the tail mass), thence extending forward as a separate cell layer, and finally appears to be blended with the loosely associated cells of the entoblast; ventrally the mesoderm, although distinctly to be recognized, is not to be separated from the cellular elements of the entoderm. In its early growth it extends forward as a wide and flattened cell mass, thinning distally and becoming confluent with the inner germ layer. As in the teleosts, gastral mesoderm is absent, and the division of the middle layer into its somatic and splanchnic layers is not apparent until a comparatively late stage of development."

Sobotta, 96, describes the origin of the mesoderm in a much earlier stage in the following words: "Nun tritt, poch ehe es zur Urdarmbildung, also zur eigentlichen Gastrulation kommt, eine Differenzirung der Furchungszellen zu Keimblättern auf, indem sich eine compacte mehrschichtige Zellage an der Oberfläche des Eies durch einen feinen Spalt von den darunten gelegenen, mit grosseren Dotterkörnern beladenen Zellen sondert (Fig. 3). Diese Erscheinung trennt bereits jetzt das Ek- 
toderm von der spater zu Mesoderm und Entoderm werdenden ZellageSehr bald beginnt nun am Aequator des Eeies die Urdarm-Bildung, und zwar zuerst an der Stelle der spateren Fmbryonalanlage. Es entsteht dadurch die dorsale Urmundlippe (Fig. 4). Letztere ist zur Zeit, wo der Urdarm als feiner Spalt sichtbar wird, sofort deutlich dreiblättrig, nicht zweiblättrig wie Dean angiebt. Die verschiedene Gehalt der Zellen an Dotterkörnern, resp. die verschiedene Grösse derselben in den Zellen, ermöglicht die Unterscheidung drier Keimblätter sehr leicht." The writer then points out the differences in the sizes of the granules in the different layers, stating that those in the cells of the ectoderm are all fine, those in the cells of the mesoderm are considerably larger, while those in the cells of the entoderm are coarse. The writer further states that when the gastral cavity has extended beneath the dorsal lip of the blastopore, the dorsal and ventral mesoderm are united.

It is evident from our studies that we agree in general with Sobotta in that we find the ectoderm early separated from the underlying layer of cells by the slit-like remains of the segmentation cavity. This underlying layer represents, according to Sobotta, the mesoderm. We do not agree, however, that in the early gastrula the size of granules or their staining capacity will enable one, as Sobotta claims, to distinguish mesoderm from entoderm. It is not until the time when the blastopore is nearly closed that a differentiation of cells is apparent. Even then we are not certain that these cells represent the mesoderm since the marked contrast in the staining capacity later disappears. To know precisely when and how the mesoderm arises and how it extends in Amia will involve better methods of staining than we now possess.

\section{The Archenteron. Kupffer's Vesicle and Adhesive Organs.}

As the archenteric cavity extends the innermost layer of mes-entoderm early is differentiated into a well defined layer which we have called hypoblast. This layer, together with the invaginated dorsal ectoblast, forms the dorsal wall of the archenteron. At the same time there is differentiated a superficial yolk layer which forms the ventral wall of the archenteron. The extent of this primitive gut, however, does not correspond to the extent of the embryo. There is formed both an appendicular (Salensky) or post-annal gut and a precephalic gut. Since the changes in the posterior portion precede those in the anterior they will be considered first.

It should be remarked here that the closure of the blastopore is complete, no portion persisting to form the anus. Its line of closure is in- 
dicated for some time by the large coarsely granular cells which lined it. The anus arises through an invagination just behind the line of closure of the blastopore and soon becomes continuous with the appendicular gut. The portion posterior to this or the post-anal gut proper soon shows retrogressive changes. The walls lose their distinctive hypoblastic character, the lumen becomes obliterated and the entire structure later disappears, playing no part in the formation of later embryo.

Kupffer's vesicle has been studied previously in Amia by Dean, 96, and Sumner, 'oo. Dean writes as follows: "The cœlenteron, now a deep cavity beneath the dorsal lip, extends forward below the entire head; its hinder dilation immediately below the dorsal lip is to be interpreted as representing Kupffer's vesicle." Regarding Dean's interpretation Sumner says: "Dean maintained that this cavity simply represented the angle formed by the blastoderm's margin, as it was mechanically turned in upon itself during its circumcrescence of the yolk. This simple mechanical explanation I cannot accept for the teleosts because (among other reasons) the vesicle in some fishes is not formed until the blastoderm has nearly or quite finished its journey over the yolk and thus the supposed mechanical cause no longer exists." In considering the function of this structure in fishes Sumner further says: "It has for some time been my view that this vesicle contains a more fluid yolk, partly assimilated through the activity of the periblast and intended for the nourishment of the growing embryo. I have also expressed the view that Kupffer's vesicle represents an embryonic digestive organ (more properly an organ of absorption)."

In considering this structure it is necessary to recall what has been said regarding the periblast in the teleosts, ganoids, and amphibia. While the roof of the vesicle in all these forms is the same, the floor in the teleosts is sometimes of periblast and again there is a cellular floor lying upon the periblast. These facts are at first difficult to interpret, yet if as H. V. Wilson, $\mathbf{9}$, suggests the latter condition is to be regarded as secondary, the difficulties are in a measure overcome. If it be accepted that the floor of Kupfer's vesicle is periblast in the teleost and that the periblast of Lepidosteus is the homologue of that of the teleost Eycleshymer, 03, we are placed in position to say that the ventral wall of the vesicle in Amia, Acipenser and the amphibia is represented by nothing more or less than the gastral floor. The vesicle then represents the posterior portion of the primitive digestive tract. This being the case in Amia no one need hesitate to accept Sumner's view that the vesicle may have had a digestive function.

The first description of the growth of the adhesive organs is given by 
Dean, 96, who says: "The mode of origin of the sucking disc gives the most interesting evidence of how precociously embryonic and larval structures may be developed. As far as histological evidence goes there is certainly no difference between the enlarged thick-walled, cup-shaped organs which arise on the snout of the late embryo of Amia or of Lepidosteus, and the typical pit organs, or sense buds, which later occur on other integumental regions. It is found, in fact, that a gradation in size exists which connects the huge sucking organs of the snout with the inconspicuous pit organs of the trunk."

These organs were later studied in Reighard's laboratory by Miss Phelps, 99, who found that " the organ is formed in a very early stage as a diverticulum of the fore gut. This diverticulum subsequently divides into two, each of which continues to communicate for a time with the cavity of the fore gut." The author further observed that the organs open to the exterior, but become cut off from the fore gut and degenerate leaving no trace behind.

Our studies show that these organs arise from paired diverticula of the fore gut and not from a single diverticulum which later divides. While it is undoubtedly correct to state that the paired gut diverticula are derived from an unpaired condition, there is not the slightest evidence that the anlagen of these structures appear before the gut diverticula are well established. The beginnings are first visible as slight thickenings of the hypoblast, forming the antero-dorsal walls of these diverticula. As development progresses these thickened areas evaginate and the cells begin to elongate. Soon a longitudinal constriction forms which divides each of these structures, giving rise to four. Meantime the lumen of each is reduced, the walls of the gut become apposed and the organs are cut off from further communication with the gut. After losing their connection with the gut they continue to divide until eight or more are formed. They then come in contact with the ectoblast whose cells undergo cytolysis, leaving the hypoblastic cells of the organs projecting to the free surface. We have not followed the later changes in these organs. Miss Phelps states that after being functional for a time the organs are pushed beneath the surface of the thickened ectoblast, become filtrated with leucocytes and finally disappear.

As to the meaning of these remarkable organs we are in the dark. Their function may be only to hold the larva in position for a certain period. Again they may serve to convey some sort of nutriment to the digestive tract. That they are modified sense buds, as Dean suggests, seems highly improbable. Their interpretation from a phylogenetic standpoint is certainly most difficult. About all that can be said is that 
structures such as these give rise to some of the most perplexing problems with which embryology has to deal.

In the surface views (Figs. 17, 18, 19) there is a peculiar median knob which appears soon after the adhesive discs are differentiated. This structure lies between and somewhat anterior to the discs. It has been observed, as earlier stated, by Reighard (see Keibel, 03). Sagittal sections through embryos of this stage ( Fig. 48) show that in addition to the lateral evaginations of the fore gut there is a less marked evagination of the median wall. The hypoblast in this region is thickened and becomes continuous on either side with that of the adhesive dises. The epiblastic pocket behind separates this structure from the anterior end of the fore brain and together with the surrounding mesoblast gives it considerable prominence in surface views. We conclude that the so-called "button" is nothing more than the strongly evaginated median portion of the adhesive organs.

\section{The Chorda and Hypochorda.}

Dean, 96, has described the formation of the chorda in Amia as follows: "The notochord arises as in the sturgeon or gar-pike: it separates directly (i. e., delaminates) from the entoderm." We have studied the origin of the notochord in many series of embryos, but are unable to add much to. Dean's description. In the great majority of cases examined the sections show conditions similar to that observed in Fig. 40; often the mesoblast has not yet separated from the axial rod as shown in Fig. 41. In but one instance have we found anything which would lead us to regard the chorda as formed by an evagination of the dorsal wall of the archenteron, as is known to be the case in many amphibia. We therefore conclude that the chorda is derived by delamination from the layers of cells which we have called mes-entoderm. The controversies that have been waged over this structure and the failure to homologize it in the various groups, especially amphibia and fishes, hold out little promise that a definite solution of the problem in harmony with the germ layer theory is near at hand.

The hypochorda, so far as we know, has not been previously seen in Amia. It arises from the hypoblast forming the dorsal wall of the gut in a stage just prior to the appearance of the pronephric ducts. It extends the length of the notochord and presents in sagittal sections appearances which lead us to regard it as irregularly segmented. This peculiar structure has been observed in many vertebrates and numerous suggestions offered as to its significance. By some it has been considered 
as the anlage of a ligament or a blood vessel. By others it is regarded as the remains of a blood vessel or of a blood-forming organ. Still others think it entirely disappears. We incline toward the last view, but our later stages are not complete enough to settle the question definitely.

\section{The Heart.}

In considering the origin of the heart, it is necessary to recall that toward the anterior end of the embryo the colomic cavities on either side approach the middle line. This approximation proceeds anteriorly until the two halves of the colomic cavities are brought closely together. Just before they meet each becomes folded back at the edge. Through this folding back of the splanchnopleure there are formed two grooves; the edges of these two grooves unite across the median line to form a single oval sac which is open both anteriorly and posteriorly. This sac is lined by entoderm and surrounded by the splanchnic mesoblast. While these changes have been going on there has appeared within the heart cavity thus formed a layer of cells which have the appearance of mesoblast cells, but apparently they are derived from the hypoblast. Whether they are to be considered as mesoblast, that at this relatively late period has differentiated from the hypoblast, or whether they are to be considered as hypoblast we are unable to say. Only by knowing the fate of these layers could one hazard an interpretation.

\section{The Central Nervous System and Sense Organs.}

The central nervous system, as observed by Dean, 96, is first formed as a solid rod or keel from the deeper ectoblast. Soon after the appearance of the optic vesicles a lumen is formed, but whether through cytolysis or delamination or both is uncertain. There are indications which lead us to regard cytolysis as the most probable.

Towards the caudal end of the embryo the superficial ectoblast folds downward into the neural keel forming the neural trench, which at the posterior end passes over into the blastopore. The question whether or not this is to be interpreted as a neurenteric canal depends upon the significance of the neural trench. If this trench is to be considered as homologous with the extreme lower part of the medullary grooves in Amniota, as Kupffer regards it in the trout, we should certainly consider its continuation over into the blastopore as a reminiscence of the neurenteric canal. However, both Wilson's and Kupffer's views are questioned by Minot and others, and since the interpretation rests upon funda- 
mentally different conceptions which are at present beyond proof or disproof, we may dismiss the question without further comment.

Concerning the neuromeres which are so well shown in Fig. 19, we can only say that at present we are unable to interpret these structures. They have not been found in the preceding stages and have not been followed in the succeeding stages. Why they should appear at this time and be wanting in the stage shown in Fig. 18, is at present unexplainable. It is impossible to state whether they are secondary foldings due to the formation of protovertebræ or whether they are formed independently in the floor of the hind brain and are the first definite expression of segments. If the latter be true, as many embryologists hold, then we should find in the hind brain of Amia indications of seven or eight primitive segments.

The median pit, which first appears in Fig. 42, has been followed in both the earlier and later stages. After a careful study much doubt lingers in our minds as to whether or not it takes any part in the formation of the hypophysis. Kupffer maintains that in Petromyzon and Acipenser this structure forms the hypophysis. It seems to us possible that the invagination of the gut to form the median portion of the adhesive organs, as shown in the figure, would carry the epiblast outward in such a manner that it results in an increase in this invagination. In other words, the mechanical factors operating could cause just the appearance observed. We should hesitate to regard this structure in Amia as of great value in phylogenetic interpretation.

The previous observations on the development of the optic vesicles in Amia are embodied in the following sentence by Dean, 96: "The mode of development of the eye and of the nasal and auditory capsules differs but little from that typical in the lower vertebrates generally." Our studies show that the eyes first appear as solid outgrowths which shortly after become hollow.

Concerning the early development of the auditory vesicle there is nothing beyond the sentence quoted above. According to our observations, the ear likewise begins as a solid thickening of the deep epiblast over which the superficial layers pass unmodified. This thickening continues until there is an oval mass lying on either side of the anterior portion of the medulla. When the embryo reaches the stage shown in Fig. 18, a cavity is present.

The olfactory organs first appear as proliferations of the deep ectoblast in the stage represented in Fig. 19. In this mass an invagination soon appears forming well defined pits. 


\section{The Pronephric Duct.}

'The pronephric duct is preceded by a solid rod of cells which arises through a proliferation of the cells of the somatopleuric portion of the mesoderm, but before the appearance of a well defined colom. We do not agree with the observations of Felix and Bühler, 04, who state that it arises as an evagination of the somatopleure. The further study does not come within the scope of the present paper.

\section{Systematic Position of Amia.}

Dean concludes his second paper, 96, on Amia with the statement that " at the base of a gradational series stands Tepidosteus, near it and in some ways even below it is Acipenser; next is Amia; next, and very closely related, is Amiurus; and, finally, are the many remaining forms of teleosts."

Previous studies by the senior author on Amia and Lepidosteus, the present study of Amia, together with the unpublished work on Ameiurus by the junior author, all indicate that such an arrangement, based upon early developmental characters, is not only premature but incorrect. The only conclusion which can be reached at the present time is that the evidence from œeology, anatomy, histology, embryology, is so fragmentary that it affords no secure basis for assigning the various ganoids their respective places within the group, nor the group its position in the vertebrate phylum.

\section{BIBLIOGRAPHY.}

Dean, BAShFoRd.-The Early Development of Amia. Quart. Jour. Micr. Sc., Vol. XXXVIII, 1896, pp. 413-444.

Dean, Bashford.-On the larval development of Amia calva. Zool. Jahrb. Abt. f. Syst., Bd IX, 1896, pp. 639-672.

Eycleshymer, Albert C.-Notes on Celloidin Technique. Am. Nat., XXVI, 1892, pp. 354-358.

Eycleshymer, Albert C.-The Cleavage of the Egg of Lepidosteus osseus. Anat. Anz., Bd. XVI, 1899, pp. 529-536.

Eycleshymer, ALrert C.-The Early Development of Lepidosteus osseus. Univ. of Chicago Decennial Publications, Chicago, 1903.

Férix and Bühler.-Die Entwickelung der Harn und Geschlechtsorgane. Handbuch d. vergl. u. exper. Entwickelung d. Wirbeltiere. O. Hertwig ed. Jena, 1904, Lief. XVIII, p. 135.

Kerr, J. Gramam.-The Development of Lepidosiren paradoxa. Part II. Quart. Jour. Micr. Sc., Vol. XI.V, 1901, pp. 1-40.

KuPFFER, C.-Studien zur vergl. Entwickelungsgeschichte des Kopfes der Kranioten. Heft I. Die Entwickelung des Kopfes von Acipenser Sturios an Medianschnitten untersucht. München, 1893, pp. 1-95. 
Phelps, Jesste.-The Development of the Adhesive Organ of Amia. Science. N. S., Vol. IX, 1899, p. 366.

Sumner, F. B.-Kupffer's Vesicle and its Relation to Gastrulation and Concrescence. Mem. New York Acad. Sci., Vol. II, 1900, Pt. 2, pp. 48-80.

SовоттA, J.-Die Gastrulation von Amia calva. Verhandl. anat. Ges., 1896, pp. 108-111.

SoвоттA, J.-Die Furchung des Wirbeltiereies. Ergebnisse Anat. und Entwickelungsgeschichte, Bd. VI, 1897, pp. 493-593.

WhitMan aNd Eycleshymer.-The Egg of Amia and its Cleavage. Jour. Morph., Vol. XII, 1896, pp. 309-354.

ZIEGLER, H. E., UND ZIEGLER, F.-Beiträge zur Entwicklungsgeschichte von Torpedo. Arch. für mikr. Anat., Bd. XXXIX, 1892, pp. 56-102.

\section{ABBREVIATIONS.}

a. g., appendicular gut.

a. $v$., auđitory vesicle.

b. c., brain cavity

ch., chorda.

d. $l$, dorsal lip of blastopore.

f. $b$., fore-brain.

g., gut.

g. d., gut diverticulum.

$h$. , anlage of head.

hch., hypochorda.

m. b., mid-brain.

mes., mesoblast.

n. c., neural canal.

$o p$. $t$, optic thickenings.

p. $c b$., pre-cerebral mass.

s. c., segmentation cavity.

$v$. a., visceral arch.

$v$. $l$, ventral lip of blastopore. $a$. $o$, adhesive organ.

$b l$., blastopore.

c.. coelom.

$d$. ec., deep ectoblast.

env., envelope.

$f$. $g$., fore-gut.

g. c., gastral cavity.

$g$. $h y$., gut hypoblast.

$h$. b., hind-brain.

$h t$., heart.

m. en., mes-entoblast.

$n$. , nasal pit.

$n$. $t$, neural trench.

$o$. $v$, optic vesicle.

p. $d$. , pronephric duct.

s. ec., superficial ectoblast.

$v$. c., visceral cleft.

$y$. m., yolk mass.

\section{EXPLANATION OF PLATES.}

\section{Plate I.}

FIG. 1. Profile view of egg about nine hours after fertilization.

FIG. 2. Profile view of egg about twelve hours after fertilization.

FIG. 3. Profile view of egg about twenty hours after fertilization.

Fig. 4. Profle view of egg about forty hours after fertilization.

Fra. 5. Profile view of egg about fifty-three hours after fertilization, anlage of embryo faintly outlined.

FIa. 6. Profile view of egg about fifty-five hours after fertilization, outline of embryo discernible.

FIG. 7. Same egg viewed from the lower pole, showing infolded blastodisc.

FIa. 8. Embryo about sixty hours after fertilization, viewed from above, embryo well defined posteriorly, neural (?) trench visible.

Fig. 9 . Embryo about sixty-five hours after fertilization, viewed from above, embryo narrower, better deflned outline, blastopore nearly closed. 
Fia. 10. Embryo about seventy hours after fertilization, embryo longer, neural (?) trench extended, blastopore closing.

Figs. 11, 12. Anterior and posterior portions of embryo about seventy-five hours after fertilization, viewed from above, optic thickenings visible, two or three protovertebrae differentiated.

Figs. 13, 14. Anterior and posterior portions of embryo, eighty hours after fertilization, viewed from above, divisions of brain and precerebral process apparent, seven to nine protovertebrae, beginnings of pronephric ducts, extent of mesoblast indicated by dark area around head.

Figs. 15, 16. Anterior and posterior portions of embryo about ninety hours after fertilization, viewed from above, showing pre-cerebral process, optic thickenings, first gill arch and cleft, about sixteen protovertebrae, dark shading around embryo indicates extent of coelom.

Fig. 17. Anterior portion of embryo about one hundred and five hours after fertilization, viewed from above, showing divisions of brain, optic vesicles, adhesive organs, median knob, two gill clefts, beginnings of auditory vesicles.

Fig. 18. Anterior portion of embryo about one hundred and ten hours after fertilization, showing slight advance beyond condition represented in Fig. 17.

Figs. 19, 20. Anterior and posterior portions of embryo about one hundred and twenty-five hours after fertilization, viewed from above, showing, in addition to structures previously described, the anlage of the heart, the beginnings of the olfactory organs, neuromeres, three gill arches and their corresponding clefts.

Plate II.

FIG. 21. Meridional section of an egg about nine hours after fertilization. Showing early condition of blastodisc segmentation cavity and yolk.

Fig. 22. Meridional section of egg about twelve hours after fertilization. Showing the yolk masses actively budding off entoblastic cells, and obscuring more or less the segmentation cavity.

FIG. 23.. Meridional section of egg about forty hours after fertilization showing proliferation of superficial ectoblast at the point where invagination begins.

Fig. 24. Meridional section of egg. about fifty hours after fertilization showing beginning of invagination and maximal thickness of blastodisc.

Fig. 25. Portion of meridional section of egg of about same age as above through region of blastopore showing first formation of mes-entoblast.

FIG. 26. Meridional section of egg slightly older than preceding stage showing further extension of gastral cavity.

Fig. 27. Meridional section of an egg about fifty-three hours after fertilization, showing reduction in number of entoblastic cells, also thinning of blastodisc.

Fig. 28. Portion of meridional section of egg in same stage as above more highly magnified, showing region of blastopore.

FIG. 29. Meridional section of an egg in stage somewhat later than above showing further thickening of margin of blastodisc.

Fig. 30. Horizontal section of egg just above level of equator, showing lateral extent of embryonic anlage, also beginning of notochord. 


\section{Plate III.}

Fig. 31. Meridional section of egg about fifty-five hours after fertilization, showing thickening of ectoblast to form head of embryo.

Fig. 32. Sagittal section of an embryo some sixty hours after fertilization showing further differentiation of embryo.

FIG. 33. Sagittal section of an embryo about sixty-three hours after fertilization, showing further growth of embryo, the obliteration of the segmentation cavity, the extension of the gastral cavity, the reduction of yolk plug.

FIG. 34. Sagittal section of posterior end of embryo about seventy hours after fertilization, showing the closure of the blastopore.

FIG. 35. Transverse section through the blastopore of an embryo in same stage as above.

FIgs. 36, 37. Sagittal section of embryo about seventy-two hours after fertilization. The anterior portion of the embryo is shown in Fig. 36, while the posterior portion is shown in Fig. 37 .

Fia. 38. Oblique section of an embryo seventy-five hours after fertilization showing the thickenings which later form the optic vesicles.

FIG. 39. Transverse section of an embryo of same age passing through the posterior portion of the hind brain.

Frg. 40. Transverse section of same embryo at the level of Kupffer's vesicle.

FIG. 41. Transverse section of an embryo of same age, showing deep neural trench and posterior end of notochord.

Fig. 42. Sagittal section of head end of embryo about ninety-five hours after fertilization, showing divisions of brain, notochord, gut, adhesive organs, and the peculiar invagination of the ectoblast just anterior to the fore-brain.

\section{Plate IV.}

Fig. 43. Transverse section through embryo of same age at the level of the adhesive organs.

Fig. 44. Transverse sections of same embryo at level of optic vesicles.

FIG. 45. Transverse section of same embryo at level of anterior margin of medulla..

FIG. 46. Transverse section of same embryo through the region of the auditory vesicles, showing the first appearance of pronephric duct and hypochorda.

Frg. 47. Transverse section of same embryo at the level of last protovertebra.

FIG. 48. Sagittal section of embryo one hundred and ten hours after fertilization, showing the beginning of the epiphysis and infundibulum, also the median portion of the adhesive organs and the heart.

FIG. 49. Transverse section of an embryo one hundred and twenty-five hours after fertilization taken just in front of the region of adhesive organs showing heart, gut and coelom.

FiG. 50.. Obliquely transverse section of an embryo of same stage passing through the anterior margin of the adhesive organs on the one side and the optic stalk and vesicle on the other, showing the approximation of the layers of the splachnopleure to form the heart. 
FIG. 51. Obliquely transverse section of same embryo taken a few sections behind that shown in Fig. 50, showing same structures as above.

FrG. 52. Transverse section of embryo in same stage showing the extension of the cavity of the auditory vesicles also the gut and coelomic cavities.

FIg. 53. Horizontal section through the head region of embryo in same stage showing various structures. 
A. O. EYCLESHYMER AND U MILSON
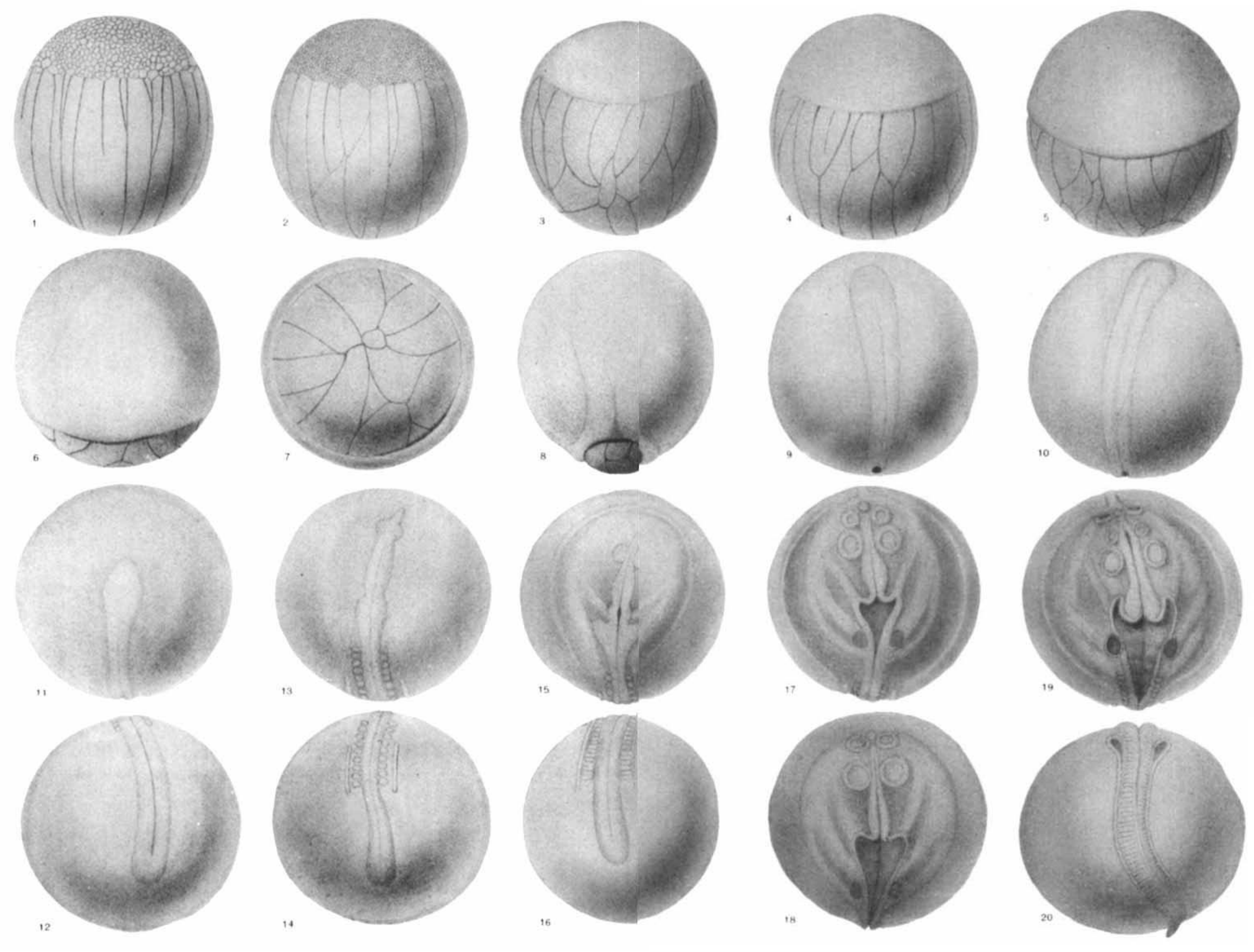

AMERICAN JOURNAL OF ANATOMY.-VOL. $v$ 


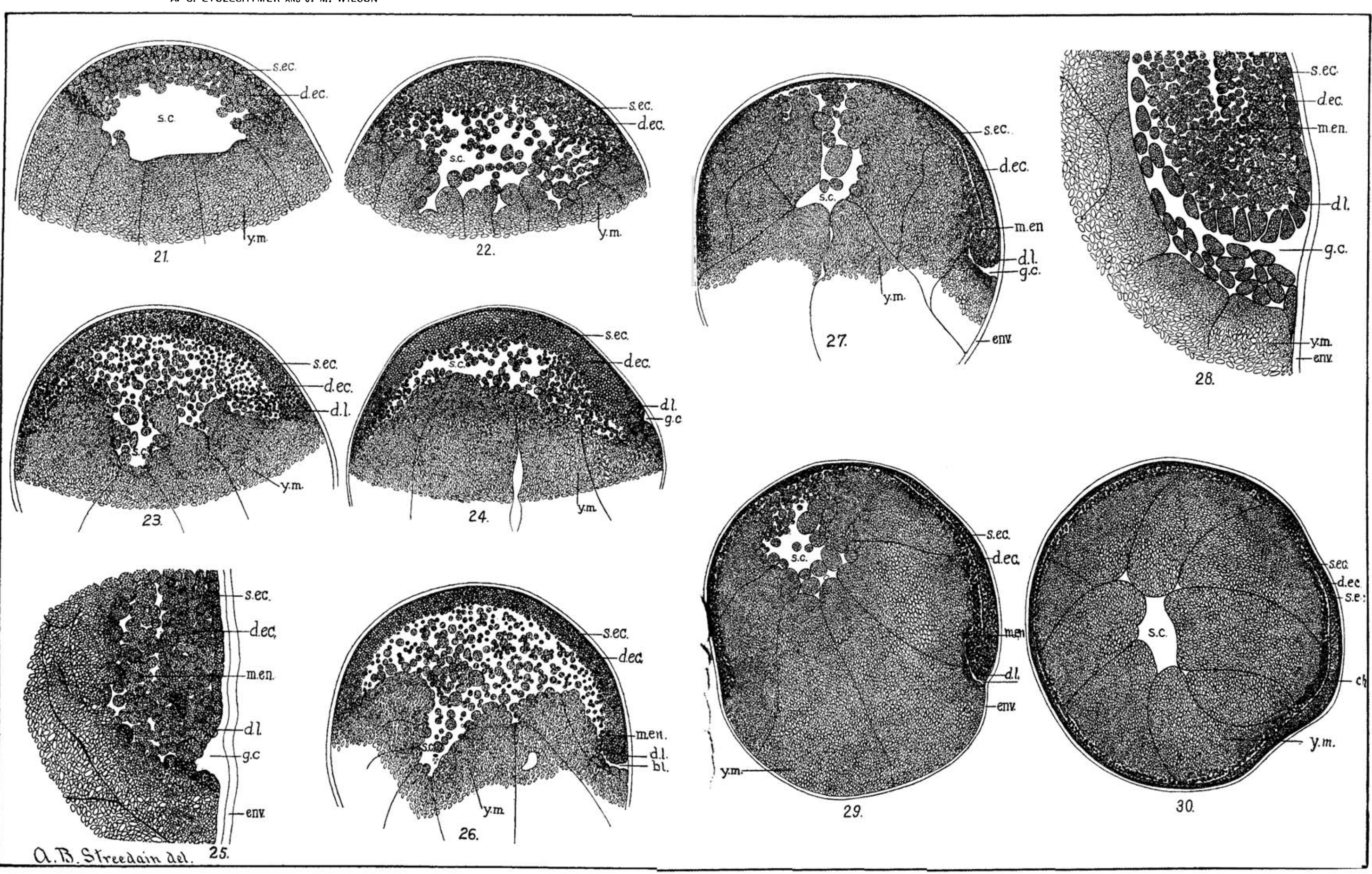




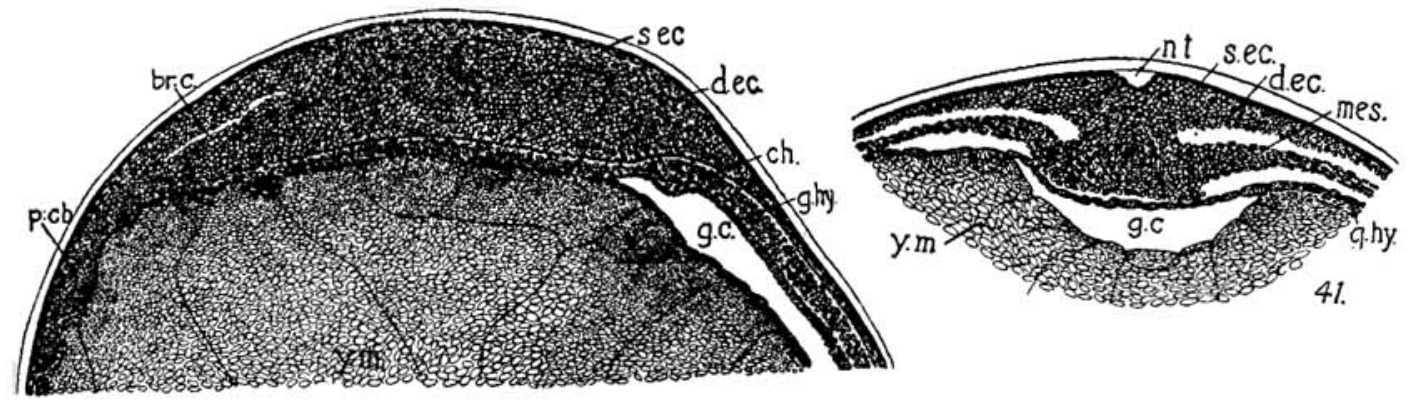

36.

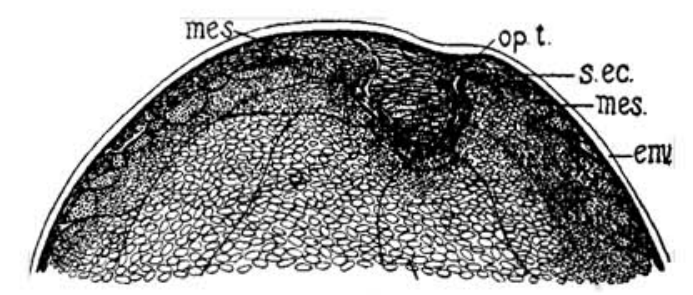

38.
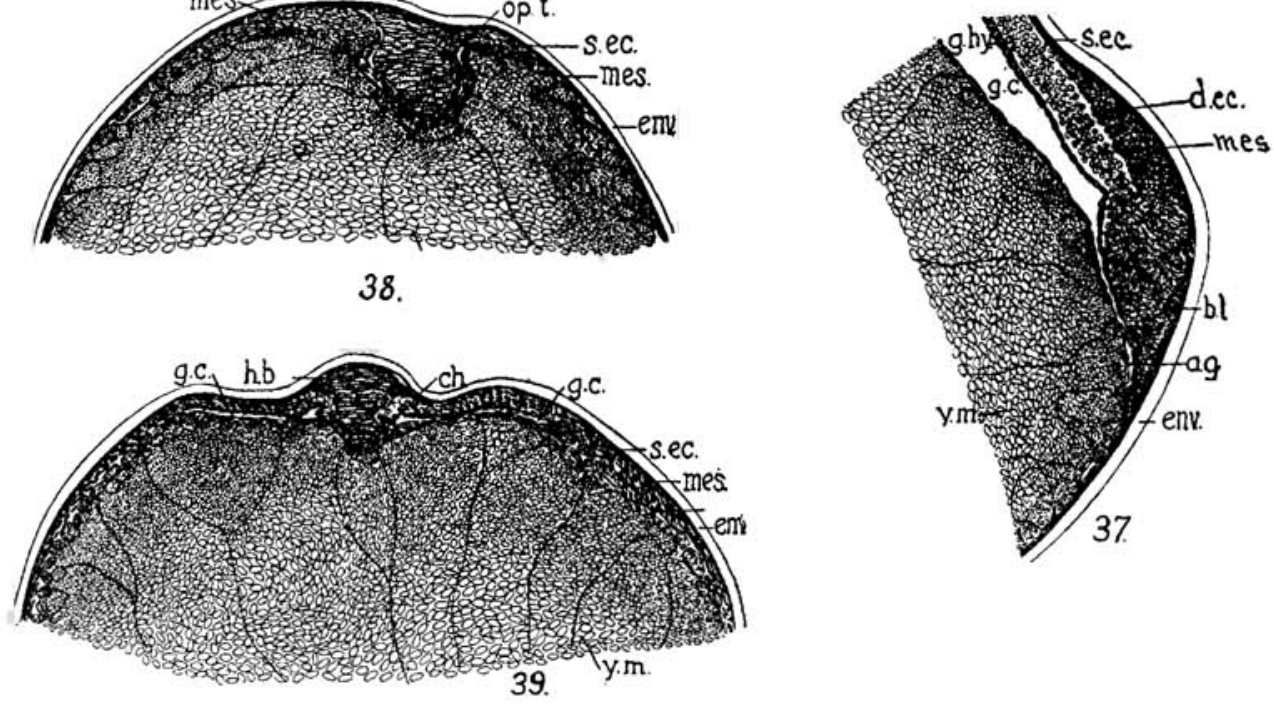

34.
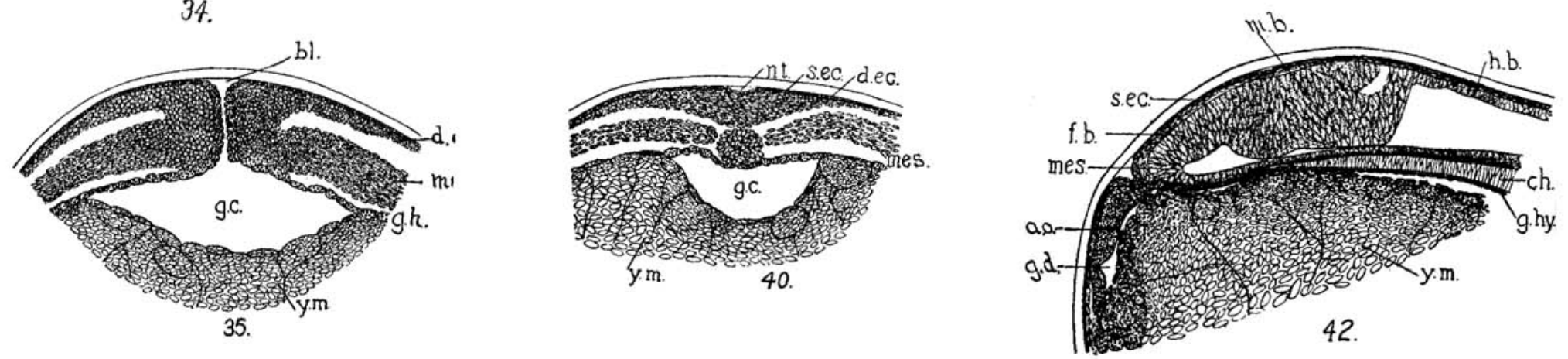

A.B Streeduin det.

AMERICAN JOURNAL OF ANATOMY--VOL. $v$ 

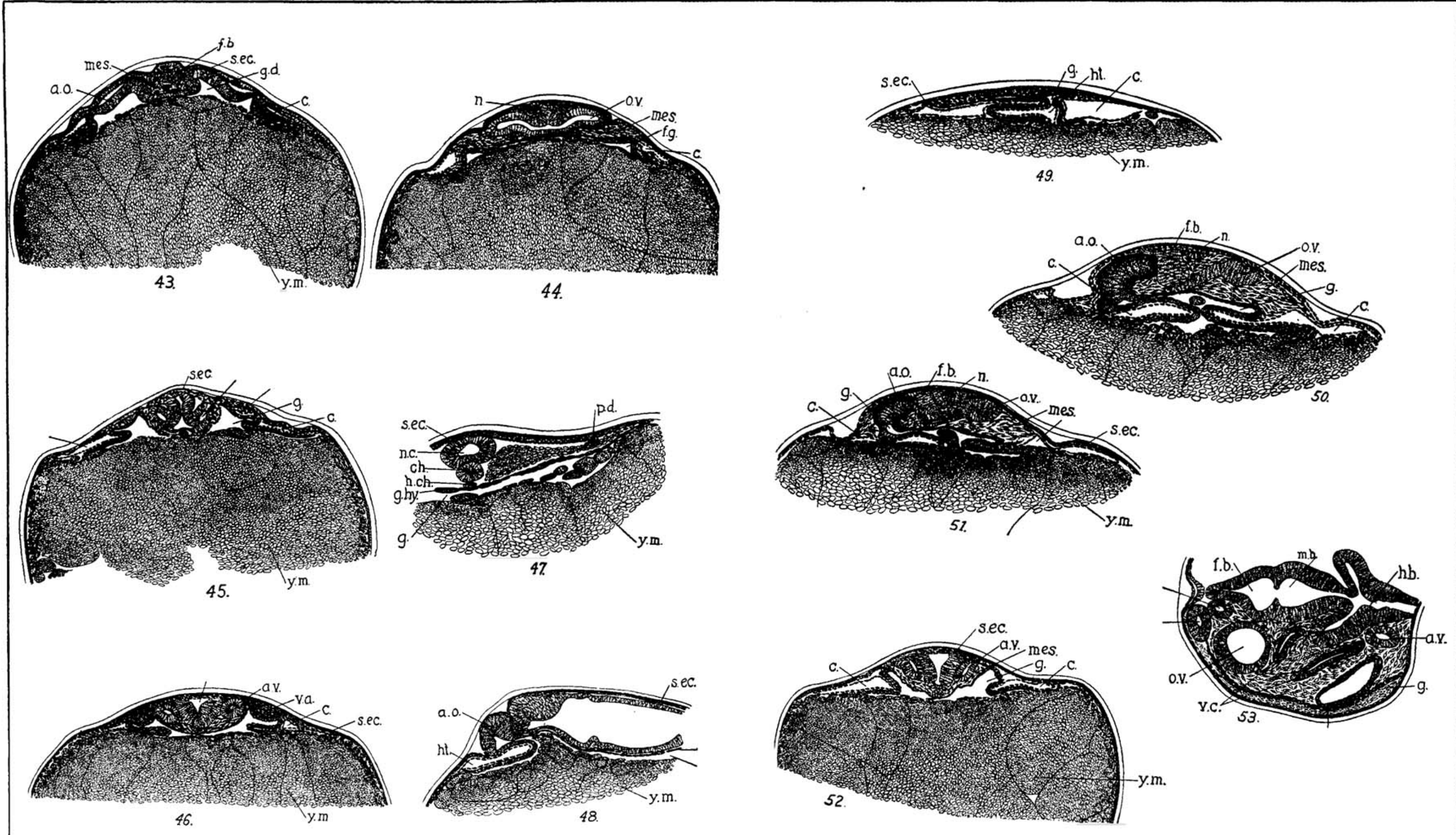

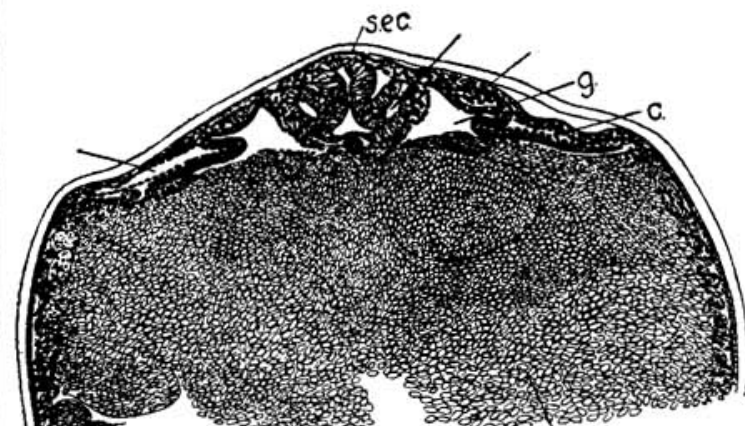

$45 . \quad y \cdot m$

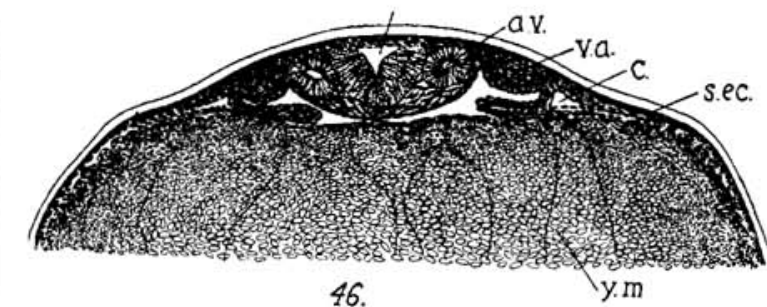

46.

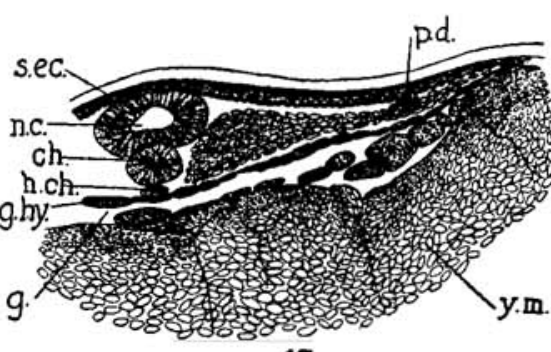

47.

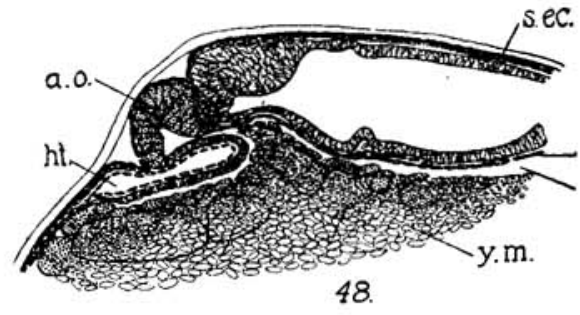

Q.B. Slireeduin del 